\title{
Characterization and diagnostic application of genomic NPM- ALK fusion sequences in anaplastic large-cell lymphoma
}

\author{
Manuela Krumbholz ${ }^{1}$, Wilhelm Woessmann ${ }^{2}$, Jakob Zierk ${ }^{1}$, David Seniuk ${ }^{1}$, Paolo \\ Ceppi $^{3}$, Martin Zimmermann ${ }^{4}$, Vijay Kumar Singh ${ }^{2}$, Markus Metzler ${ }^{1, *}$ and Christine \\ Damm-Welk ${ }^{2, *}$ \\ ${ }^{1}$ University Hospital Erlangen, Department of Pediatrics, Erlangen, Germany \\ ${ }^{2}$ Justus-Liebig University, Department of Pediatric Hematology and Oncology, Giessen, Germany \\ ${ }^{3}$ Junior Research Group 1, Interdisciplinary Centre for Clinical Research, Friedrich-Alexander-University Erlangen-Nürnberg \\ (FAU), Erlangen, Germany \\ ${ }^{4}$ Hannover Medical School, Department of Pediatric Hematology and Oncology, Hannover, Germany \\ *These authors have contributed equally to this work \\ Correspondence to: Manuela Krumbholz, email: Manuela.Krumbholz@uk-erlangen.de \\ Keywords: pediatric oncology; ALK-positive anaplastic large cell lymphoma; NPM-ALK fusion; genomic fusion sequences; minimal \\ disease monitoring \\ Received: February 01, $2018 \quad$ Accepted: May 07, $2018 \quad$ Published: May 29, 2018 \\ Copyright: Krumbholz et al. This is an open-access article distributed under the terms of the Creative Commons Attribution License \\ 3.0 (CC BY 3.0), which permits unrestricted use, distribution, and reproduction in any medium, provided the original author and \\ source are credited.
}

\section{ABSTRACT}

Nucleophosmin-anaplastic lymphoma kinase (NPM-ALK) fusion genes resulting from the translocation $t(2 ; 5)(p 23 ; q 35)$ are present in almost $90 \%$ of childhood ALK-positive anaplastic large-cell lymphomas (ALCL). Detection and quantification of minimal disseminated disease (MDD) by measuring NPM-ALK fusion transcript levels in the blood provide independent prognostic parameters. Characterization of the genomic breakpoints provides insights into the pathogenesis of the translocation and allows for DNA-based minimal disease monitoring.

We designed a nested multiplex PCR assay for identification and characterization of genomic NPM-ALK fusion sequences in 45 pediatric ALCL-patients, and used the sequences for quantitative MDD monitoring. Breakpoint analysis indicates the involvement of inaccurate non-homologous end joining repair mechanisms in the formation of NPM-ALK fusions. Parallel quantification of RNA and DNA levels in the cellular fraction of 45 blood samples from eight patients with NPM-ALK-positive ALCL correlated, as did cell-free circulating NPM-ALK DNA copies in the plasma fraction of 37 blood samples. With genomic NPM-ALK fusion sequence quantification, plasma samples of ALCL patients become an additional source for MRD-assessment. Parallel quantification of NPM-ALK transcripts and fusion genes in ALCL cell lines treated with the ALK kinase inhibitor crizotinib illustrates the potential value of supplementary DNA-based quantification in particular clinical settings.

\section{INTRODUCTION}

ALK-positive anaplastic large-cell lymphoma (ALCL) accounts for $10-15 \%$ of pediatric non-Hodgkin lymphoma (NHL) cases [1]. Almost $90 \%$ of pediatric ALCL carry the chromosomal translocation $\mathrm{t}(2 ; 5)$ (p23; 335 ) resulting in the fusion of the nucleophosmin $(N P M)$ gene and the anaplastic lymphoma kinase $(A L K)$ gene [2-4]. The NPM-ALK fusion protein is a constitutively active tyrosine kinase that is heavily involved in tumor pathogenesis and maintenance [5].

The pathogenic mechanisms involved in the generation of the $N P M-A L K$ fusion gene have not been 
analyzed in patients thus far. A systematic analysis of genomic fusion sequences from ALCL patients could provide insights into the pathogenesis of the translocation. The genomic fusion sites consistently fall within specific breakpoint cluster regions that comprise a $1 \mathrm{~kb}$ region around intron 4 within the $N P M$ gene and a $2.2 \mathrm{~kb}$ region between exon 19 and exon 20 within the $A L K$ gene [6, 7].

Standard multi-agent chemotherapy reaches eventfree survival rates of $70 \%$ at five years [8-11]. New therapeutic options are available to be tested for patients with a high relapse risk in addition to chemotherapy (e.g., ALK-kinase inhibitors or Brentuximab Vedotin) or for those with a low relapse risk as a lower toxicity backbone (Vinblastine monotherapy) [12-14]. Therefore, reliable prognostic factors are necessary. The tumorspecific $N P M-A L K$ fusion transcript has been established as a minimal disease marker in both bone marrow and blood mononuclear cells. Several groups have established detection protocols for minimal disseminated disease (MDD) by qualitative PCR for NPM-ALK mRNA as an independent and potent prognostic parameter under BFM pulse-type chemotherapy [15-19]. Fifty-five to sixty percent of patients are MDD-positive, and their risk of relapse is about $50 \%$ compared to $15 \%$ for MDD-negative patients [15-18]. Quantification of MDD has been shown by one group to detect patients with very high risk of relapse of $70 \%$ [17]. Detection of minimal residual disease (MRD) before the second course of chemotherapy allowed for definition of very high-risk patients with a relapse risk of almost $80 \%$, as well [18]. However, despite the proven reliability of the MDD-marker at the RNA level, the use of RNA has some intrinsic disadvantages such as possible degradation by RNases during transport of blood samples to central laboratories. In addition, supplementary quantification of DNA fusion sequences would allow for calculation of absolute tumor cell numbers independent of gene expression, and detection of quiescent tumor cells. The fact that the breakpoint cluster regions in the NPM and $A L K$ genes in ALCL are relatively small facilitates the design of fusion gene detection assays.

In the present study, we developed a nested multiplex PCR assay for identification of genomic $N P M-A L K$ fusion sequences and performed a detailed characterization of the genomic breakpoints in pediatric ALCL. We evaluated the genomic fusion sequence as a supplementary tool for minimal disease assessment in both the cellular and plasma fractions of blood in children and adolescents with ALK-positive ALCL.

\section{RESULTS}

\section{Characterization of genomic $N P M$ and $A L K$ breakpoints in ALCL patients}

The nested multiplex PCR assay enabled identification of the genomic $A L K$ fusion sequences in all four tested ALK+ cell lines (Karpas 299, SR-786, L-82, and SuDHL-1) and in all 45 ALCL patients (Table 1).

In 43 patients, NPM was the fusion partner of ALK. ATIC and TPM3 were the fusion partners in the two remaining patients, respectively (Figure 1A). In one patient (UPN31), the $N P M-A L K$ fusion gene was not detectable, but the reciprocal $A L K-N P M$ fusion gene could be sequenced. In 30 ALCL patients and one cell line $(\mathrm{SuDHL}-1)$, we were able to detect both derivative fusion sites (NPM-ALK and $A L K-N P M)$. There were no cases with a perfectly balanced translocation: nearly all patients had deletions at the fusion region with a median deletion size of 55 base pairs (bp) in $N P M$ and 49 bp in ALK (Table 1).

The alignment of the genomic breakpoints to the breakpoint cluster region (bcr) of NPM showed a random distribution with no sub-clusters (Figure 1A-1B). All NPM breakpoints identified were located in intron 4 and were randomly distributed therein. Genomic breakpoints within the $A L K$ bcr were mostly located in intron 19 (93\%), with 3 breakpoints in exon 19 (7\%). Although genomic $A L K$ breakpoints appeared to be enriched in the first half of intron 19, kernel density analysis did not identify any significant clustering (Figure 1B).

Detailed characterization of the NPM-ALK fusion sites showed small microhomologies ( 1 to $6 \mathrm{bp}$ ) in $38 \%$ of patients and small fillers ( 1 to $8 \mathrm{bp}$ ) in $22 \%$ of patients (Figure 1C). These findings indicate that the formation of $N P M-A L K$ translocations in ALCL involves inaccurate non-homologous end joining (NHEJ) repair mechanisms [20].

We further analyzed the genomic breakpoints for co-localization with repeat regions or with other DNA sequence motifs that could support the initiation of ALCL chromosomal translocation as described for other lymphoma subtypes [21, 22]. No significant correlation could be observed with repeat elements or other sequence motifs at the exact breakpoint position or expanded breakpoint regions (plus 50 bp upstream and downstream) that suggest an inaccurate DNA strand repair at the fusion site (Figure 2).

\section{Comparative quantification of $N P M-A L K$ fusion transcripts and $N P M-A L K$ fusion gene sequences in blood and plasma samples}

To evaluate the potential application of DNAbased minimal disease monitoring for ALCL patients, we compared the standard RNA-based technique with DNAbased quantification using patients' individual fusion sequences from both the cellular and plasma fractions in 51 blood samples. The 51 samples were collected from eight high-risk patients identified as MDD-positive by the standard method during the course of their treatment. Seven of the patients relapsed. Consequently, more than half the samples showed quantifiable copy numbers using 
Table 1: Patient's characteristics and genomic breakpoint positions

\begin{tabular}{|c|c|c|c|c|c|c|c|c|c|c|c|}
\hline \multirow{2}{*}{$\begin{array}{l}\text { Patient } \\
\text { ID }\end{array}$} & \multirow{2}{*}{$\begin{array}{l}\text { Age at } \\
\text { diagnosis } \\
\text { (years) }\end{array}$} & \multirow{2}{*}{ Sex } & \multirow{2}{*}{$\begin{array}{c}\text { Minimal } \\
\text { disseminated } \\
\text { disease }\end{array}$} & \multicolumn{2}{|c|}{$\begin{array}{c}\text { Break position NPM1-ALK } \\
\text { (GRCh37/hg19) }\end{array}$} & \multirow{2}{*}{$\begin{array}{l}\text { Filler } \\
\text { (bp) }\end{array}$} & \multirow{2}{*}{$\begin{array}{c}\text { Micro- } \\
\text { homologies } \\
\text { (bp) }\end{array}$} & \multicolumn{2}{|c|}{$\begin{array}{c}\text { Break position } A L K- \\
\text { NPM1 (GRCh37/hg19) }\end{array}$} & \multicolumn{2}{|c|}{ gains and losses (bp) } \\
\hline & & & & NPM1 (chr5:) & $\begin{array}{c}A L K \\
\text { (chr2:) }\end{array}$ & & & $\begin{array}{c}A L K \\
\text { (chr2:) }\end{array}$ & $\begin{array}{l}\text { NPM1 } \\
\text { (chr5:) }\end{array}$ & NPM1 & $A L K$ \\
\hline UPN1 & 7.2 & $\mathrm{f}$ & negative & $170,818,898$ & $29,447,090$ & 8 & 0 & $29,447,105$ & $170,818,917$ & -18 & -14 \\
\hline UPN2 & 14.8 & $\mathrm{~m}$ & positive & $170,819,445$ & $29,446,546$ & 0 & 0 & & & & \\
\hline UPN3 & 8.4 & $\mathrm{~m}$ & positive & $170,819,197$ & $29,447,296$ & 0 & 2 & & & & \\
\hline UPN4 & 15.7 & $\mathrm{~m}$ & positive & $170,819,221$ & $29,447,309$ & 0 & 2 & & & & \\
\hline UPN5 & 15.4 & $\mathrm{~m}$ & positive & $170,818,960$ & $29,447,677$ & 0 & 0 & $29,447,718$ & $170,819,094$ & -133 & -40 \\
\hline UPN6 & 16.1 & $\mathrm{f}$ & positive & $170,819,226$ & $29,447,374$ & 0 & 0 & $29,447,408$ & $170,819,307$ & -80 & -33 \\
\hline UPN7 & 11.5 & $\mathrm{~m}$ & n.a. & $170,819,006$ & $29,448,395$ & 0 & 2 & $29,448,420$ & $170,819,032$ & -25 & -24 \\
\hline UPN8 & 12 & $\mathrm{f}$ & positive & $170,819,682$ & $29,447,119$ & 0 & 0 & $29,447,177$ & $170,819,740$ & -57 & -57 \\
\hline UPN9 & 15 & $\mathrm{~m}$ & positive & $170,819,566$ & $29,447,140$ & 0 & 0 & $29,447,199$ & $170,819,643$ & -76 & -58 \\
\hline UPN10 & 16.7 & $\mathrm{f}$ & positive & $170,818,883$ & $29,448,215$ & 0 & 1 & & & & \\
\hline UPN11 & 14.4 & $\mathrm{~m}$ & positive & $170,819,131$ & $29,447,024$ & 0 & 0 & $29,447,084$ & $170,819,157$ & -23 & -59 \\
\hline UPN12 & 10.1 & $\mathrm{~m}$ & negative & $170,819,664$ & $29,448,341$ & 0 & 1 & $29,448,366$ & $170,819,728$ & -63 & -24 \\
\hline UPN13 & 7.2 & $\mathrm{~m}$ & negative & $170,819,274$ & $29,447,701$ & 0 & 0 & $29,447,725$ & $170,819,344$ & -69 & -23 \\
\hline UPN14 & 3.9 & $\mathrm{f}$ & positive & $170,819,591$ & $29,446,607$ & 0 & 3 & $29,446,646$ & $170,819,634$ & -42 & -38 \\
\hline UPN15 & 4.6 & $\mathrm{~m}$ & n.a. & $170,819,293$ & $29,448,101$ & 0 & 2 & & & & \\
\hline UPN16 & 17.2 & $\mathrm{f}$ & positive & $170,819,070$ & $29,447,988$ & 0 & 0 & $29,448,046$ & $170,819,099$ & -28 & -57 \\
\hline UPN17 & 7.7 & $\mathrm{~m}$ & negative & $170,819,660$ & $29,447,251$ & 0 & 0 & $29,447,282$ & $170,819,686$ & -25 & -30 \\
\hline UPN18 & 15.6 & $\mathrm{f}$ & positive & $170,818,991$ & $29,448,172$ & 0 & 1 & $29,448,178$ & $170,819,017$ & -25 & -5 \\
\hline UPN19 & 11.7 & $\mathrm{f}$ & negative & $170,819,466$ & $29,447,635$ & 0 & 3 & $29,447,657$ & $170,819,527$ & -60 & -21 \\
\hline UPN20 & 11.2 & $\mathrm{f}$ & negative & $170,819,157$ & $29,447,876$ & 0 & 0 & & & & \\
\hline UPN21 & 15 & $\mathrm{f}$ & positive & $170,819,544$ & $29,446,623$ & 1 & 0 & $29,446,648$ & $170,819,645$ & -100 & -24 \\
\hline UPN22 & 13.8 & $\mathrm{f}$ & positive & $170,819,488$ & $29,446,635$ & 0 & 2 & $29,446,709$ & $170,819,515$ & -26 & -73 \\
\hline UPN23 & 8.1 & $\mathrm{~m}$ & negative & $170,818,958$ & $29,447,699$ & 2 & 0 & $29,447,817$ & $170,819,068$ & -109 & -117 \\
\hline UPN24 & 3.5 & $\mathrm{f}$ & negative & $170,819,590$ & $29,446,702$ & 2 & 0 & & & & \\
\hline UPN25 & 8.1 & $\mathrm{~m}$ & n.a. & $\begin{array}{l}\text { chr2: } 216,195,742 \\
\text { (ATIC) }\end{array}$ & $29,446,788$ & 0 & 2 & & & & \\
\hline UPN26 & 5.3 & $\mathrm{~m}$ & negative & $170,819,658$ & $29,448,164$ & 0 & 1 & $29,448,178$ & $170,819,732$ & -73 & -13 \\
\hline UPN27 & 11.4 & $\mathrm{f}$ & positive & $170,819,690$ & $29,448,219$ & 2 & 0 & $29,448,355$ & $170,819,742$ & -51 & -135 \\
\hline UPN28 & 8.7 & $\mathrm{~m}$ & n.a. & $\begin{array}{l}\operatorname{chr} 1: 154,130,428 \\
\text { (TPM3) }\end{array}$ & $29,448,416$ & 0 & 0 & & & & \\
\hline UPN29 & 13.7 & $\mathrm{~m}$ & positive & $170,819,465$ & $29,447,764$ & 1 & 0 & $29,447,878$ & $170,819,504$ & -38 & -113 \\
\hline UPN30 & 15.3 & $\mathrm{~m}$ & positive & $170,819,429$ & $29,447,734$ & 1 & 0 & $29,447,806$ & $170,819,515$ & -85 & -71 \\
\hline UPN31 & 7.9 & $\mathrm{~m}$ & positive & & & 0 & 0 & $29,448,297$ & $170,818,878$ & & \\
\hline UPN32 & 8.7 & $\mathrm{~m}$ & positive & $170,819,385$ & $29,447,917$ & 0 & 2 & $29,448,006$ & $170,819,481$ & -95 & -88 \\
\hline UPN33 & 12.7 & $\mathrm{f}$ & positive & $170,819,254$ & $29,446,584$ & 6 & 0 & & & & \\
\hline UPN34 & 16.9 & $\mathrm{f}$ & n.a. & $170,819,500$ & $29,447,765$ & 0 & 0 & & & & \\
\hline UPN35 & 13.3 & $\mathrm{f}$ & n.a. & $170,819,320$ & $29,446,715$ & 1 & 0 & $29,446,736$ & $170,819,362$ & -41 & -20 \\
\hline UPN36 & 2.5 & $\mathrm{f}$ & n.a. & $170,819,658$ & $29,447,102$ & 0 & 6 & $29,447,135$ & $170,819,768$ & -109 & -29 \\
\hline UPN37 & 14.4 & $\mathrm{~m}$ & positive & $170,819,079$ & $29,447,311$ & 0 & 0 & $29,447,381$ & $170,819,113$ & -33 & -69 \\
\hline
\end{tabular}




\begin{tabular}{|c|c|c|c|c|c|c|c|c|c|c|c|}
\hline \multirow{2}{*}{$\begin{array}{l}\text { Patient } \\
\text { ID }\end{array}$} & \multirow{2}{*}{$\begin{array}{l}\text { Age at } \\
\text { diagnosis } \\
\text { (years) }\end{array}$} & \multirow{2}{*}{ Sex } & \multirow{2}{*}{$\begin{array}{l}\text { Minimal } \\
\text { disseminated } \\
\text { disease }\end{array}$} & \multicolumn{2}{|c|}{$\begin{array}{c}\text { Break position NPM1-ALK } \\
\text { (GRCh37/hg19) }\end{array}$} & \multirow{2}{*}{$\begin{array}{l}\text { Filler } \\
\text { (bp) }\end{array}$} & \multirow{2}{*}{$\begin{array}{c}\text { Micro- } \\
\text { homologies } \\
\text { (bp) }\end{array}$} & \multicolumn{2}{|c|}{$\begin{array}{c}\text { Break position } A L K- \\
\text { NPM1 (GRCh37/hg19) }\end{array}$} & \multicolumn{2}{|c|}{ gains and losses (bp) } \\
\hline & & & & NPM1 (chr5:) & $\begin{array}{c}A L K \\
\text { (chr2:) }\end{array}$ & & & $\begin{array}{c}A L K \\
\text { (chr2:) }\end{array}$ & $\begin{array}{l}\text { NPM1 } \\
\text { (chr5:) }\end{array}$ & NPM1 & $A L K$ \\
\hline UPN38 & 3.1 & $f$ & negative & $170,819,367$ & $29,447,597$ & 0 & 0 & & & & \\
\hline UPN39 & 10.4 & $\mathrm{~m}$ & positive & $170,819,176$ & $29,447,498$ & 0 & 0 & $29,447,548$ & $170,819,238$ & -61 & -49 \\
\hline UPN40 & 14.6 & $\mathrm{~m}$ & positive & $170,819,186$ & $29,447,815$ & 0 & 0 & & & & \\
\hline UPN41 & 4.2 & $\mathrm{f}$ & negative & $170,819,308$ & $29,447,888$ & 0 & 1 & $29,447,940$ & $170,819,364$ & -55 & -51 \\
\hline UPN42 & 7.4 & $\mathrm{~m}$ & negative & $170,819,252$ & $29,446,761$ & 6 & 0 & $29,446,893$ & $170,819,280$ & -27 & -131 \\
\hline UPN43 & 12.2 & $\mathrm{~m}$ & positive & $170,819,441$ & $29,447,645$ & 0 & 3 & $29,447,748$ & $170,819,552$ & -110 & -102 \\
\hline UPN44 & 5.6 & $\mathrm{~m}$ & positive & $170,818,895$ & $29,447,740$ & 0 & 0 & $29,447,766$ & $170,818,950$ & -54 & -25 \\
\hline UPN45 & 14.9 & $\mathrm{~m}$ & positive & $170,819,724$ & $29,446,564$ & 0 & 1 & & & & \\
\hline \multicolumn{12}{|l|}{$\begin{array}{l}\text { Cell } \\
\text { lines: }\end{array}$} \\
\hline $\begin{array}{l}\text { Karpas } \\
299\end{array}$ & 25 & $\mathrm{~m}$ & l & $170,819,509$ & $29,448,184$ & 0 & 0 & & & & \\
\hline SuDHL-1 & 10 & $\mathrm{~m}$ & l & $170,819,668$ & $29,447,024$ & 7 & 0 & $29,447,105$ & $170,819,618$ & 51 & -80 \\
\hline SR-786 & 11 & $\mathrm{~m}$ & l & $170,819,199$ & $29,446,897$ & 0 & 0 & & & & \\
\hline L-82 & 24 & $\mathrm{w}$ & l & $170,819,583$ & $29,447,947$ & 0 & 2 & & & & \\
\hline
\end{tabular}

n.a. not available.

RNA-based MDD/MRD measurement. This provided sufficient samples with measurable copy numbers for a quantitative comparison of the two methods.

$N P M-A L K$ transcripts in the mononuclear cell fraction were quantifiable in 48 of the 51 samples (when applying the quality criteria of 2000 copies $A B L$ ). Of those 48 samples, 23 were negative and 25 positive. Three of the 48 samples quantifiable by RT-qPCR were not quantifiable by the DNA-based assay. Conversely, the DNA-based assay was able to quantify eight samples that could not be evaluated at the RNA-level (Supplementary Table 1).

The DNA breakpoint method and the standard RNA method were well correlated for $N P M-A L K$ quantification, with a correlation coefficient of $0.77(\mathrm{p}<0.0001)$ (Figure $3 \mathrm{~A})$. Eight samples identified as negative by the RNAbased method were identified as positive at the DNA level, usually with very low copy numbers $(0.08,0.2,0.7,0.8$, 1, 2.1, 4.7, $24 N P M-A L K / 10^{4} A L B$ copies). Three samples identified as negative at the DNA-level had measurable RNA-copies (1.1, 1.1, and 1.6 NPM-ALK/10 $4 B L$ copies).

In 37 available concordant plasma and cell samples, we were able to perform NPM-ALK quantification with RNA in the cellular fraction and with cell-free circulating tumor DNA (ctDNA) in the plasma fraction. Spearman's correlation revealed a correlation of ctDNA quantification data with $N P M-A L K$ RNA levels $(\mathrm{r}=0.77, \mathrm{p}<0.0001)$ as well as with cellular NPM-ALK DNA levels $(\mathrm{r}=0.81, \mathrm{p}<$ 0.0001) (Figure 3).

Examples of the course of MRD quantification of initially MDD-positive patients for three patients are shown in Figure 4. Patient UPN45 was MDD-positive using RNA and DNA based quantification. The patient's MRD then became negative in cells (RNA and DNA level) and plasma (ctDNA) before the second course of chemotherapy, and stayed MRD negative in all available following timepoints according to all three methods. Patient UPN35, however, never became MRD negative according to any of the methods and suffered two relapses. These two patients showed complete concordance between all three methods.

Despite the overall correlation of the MRD results obtained by both the RNA and DNA methods, the MRD course of patient UPN43 contained two timepoints at which $N P M-A L K$ was detectable by the DNA-based method at low copy numbers while fusion gene transcripts were not. The prognostic important MRD timepoint before the second course of chemotherapy [18], however, showed concordance in all three patients.

\section{In vitro evaluation of RNA- and DNA-based therapy monitoring during treatment with ALK kinase inhibitors}

To evaluate whether DNA-based minimal disease measurement might provide additional information beyond the standard RNA-based method, we compared RNA- and DNA-based quantification of NPM-ALK fusion sequences in two ALK+ ALCL cell lines (Karpas 299 and SR-786) incubated with different concentrations of the ALK kinase inhibitor crizotinib for 72 hours (Figure 5). To measure changes in $N P M-A L K$ fusion genes and fusion gene transcripts under minimal disease conditions, ALK- 
negative DG-75 cells were added to the ALK+ ALCL cells for a dilution of 1:100. We also determined the amount of living and dead cells following the 72-hour exposure (Figure 5).

In the SR-786/DG75 cell suspension mix, we observed a concentration-dependent reduction of the NPM$A L K$ fusion transcripts after 72 hours of incubation with crizotinib (Figure 5A). At the DNA level, the reduction was far less pronounced (Figure 5B). The ratio of NPM$A L K$ RNA to DNA revealed reduced NPM-ALK expression per $N P M$ - $A L K$-containing cell (Figure $5 \mathrm{C}$ ). In concordance with the results of our cell death measurements, $N P M-A L K$ quantification was not significant reduced at either the RNA level or the DNA level after $72 \mathrm{~h}$ of incubation with crizotinib. In contrast to SR-786 cells, the less sensitive cell line Karpas 299 (Figure 5D) shows a lower reduction of NPM-ALK RNA transcripts even after treatment with the highest concentration (1000 nM crizotinib) (Figure $5 \mathrm{~A}$ ) that results in nearly constant $\mathrm{RNA} / \mathrm{DNA}$ ratios (Figure 5C).

\section{DISCUSSION}

In the present study, we established a multiplex PCR assay for the detection of genomic NPM-ALK fusion sequences in children with ALK-positive ALCL in order to investigate the pattern of fusion sites in ALCL and to assess genomic breakpoints as biomarkers for minimal disease quantification. Our multiplex PCR assay identified the genomic fusion gene sequences in all 45 pediatric ALCL patients investigated, permitting further characterization of the breakpoint features and breakpoint distribution in a large cohort of ALK-positive pediatric ALCL patients.

Of the few genomic $N P M-A L K$ fusion sequences that have been previously published, all were identified with long-range or nested long-range PCRs [6, 7, 23-25]. These methods require high-molecular-weight DNA that often cannot be retrieved from the formalin-fixed, paraffinembedded tumor tissue available from routine diagnostics. Our multiplex PCR, however, is less dependent on highquality DNA because it generates smaller amplification products. The NPM-ALK breakpoint distribution allows complete coverage of the breakpoint cluster regions with multiplex PCR compatible primer numbers. In principle, genomic fusion sequences can also be identified with library enrichment strategies and next generation sequencing techniques that allow parallel sequencing of several patients in an automated pipeline. Given the small breakpoint cluster regions in the NPM and ALK gene, easily accessible with one multiplex PCR assay, and the rare occurrence of this disease, costly enrichment assays in
A

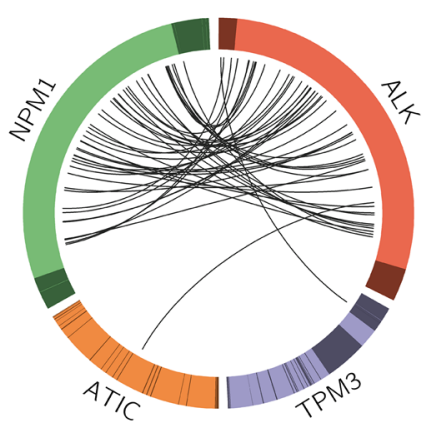

C

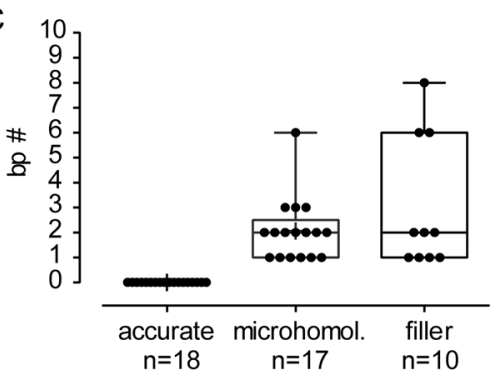

B

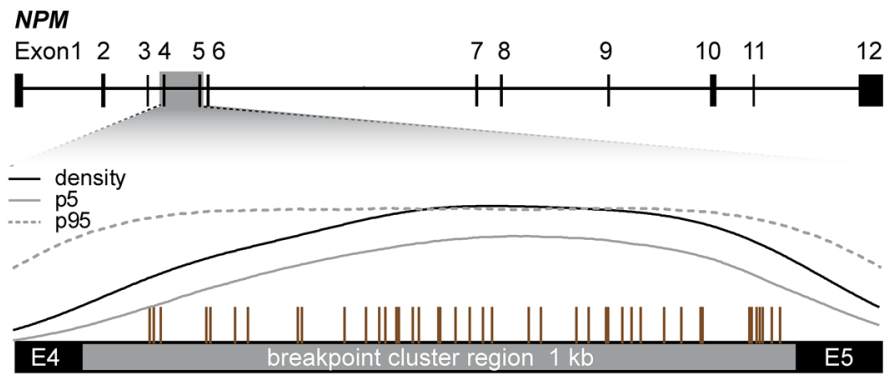

ALK
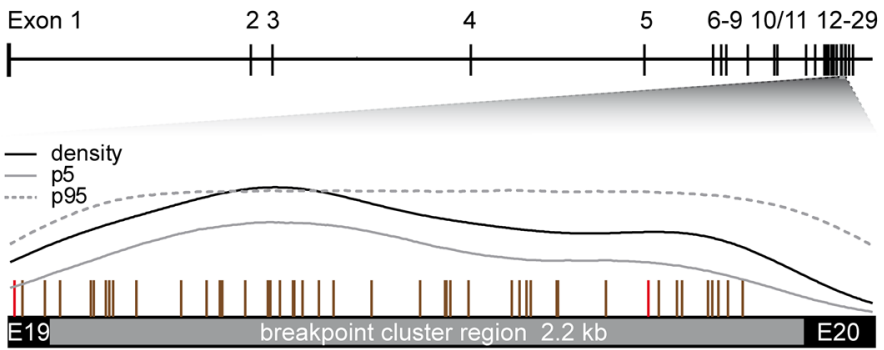

Figure 1: Breakpoint distribution in $A L K$ and the respective fusion partner gene in 45 pediatric ALK-positive ALCL patients. (A) Circos plot presents the genomic rearrangements within the $A L K$ breakpoint cluster region (bcr), $N P M$ bcr, $A T I C$ gene, and $T M P 3$ gene. Exons are illustrated in darker colors. (B) Genomic organization of the $N P M$ and $A L K$ gene with the corresponding bcr. Vertical bars above the bcr represent individual genomic breakpoints. Results of Kernel density analysis: dashed line = breakpoint density; gray line $=$ lower limit of $95 \%$ confidence band determined by bootstrapping procedure; black line $=95 \%$ confidence interval of a density function resulting from simulations at randomly distributed pseudo-breakpoints. (C) Boxplot represents the median and range of nucleotide numbers involved in microhomologies and fillers at the individual $N P M-A L K$ fusion site. 

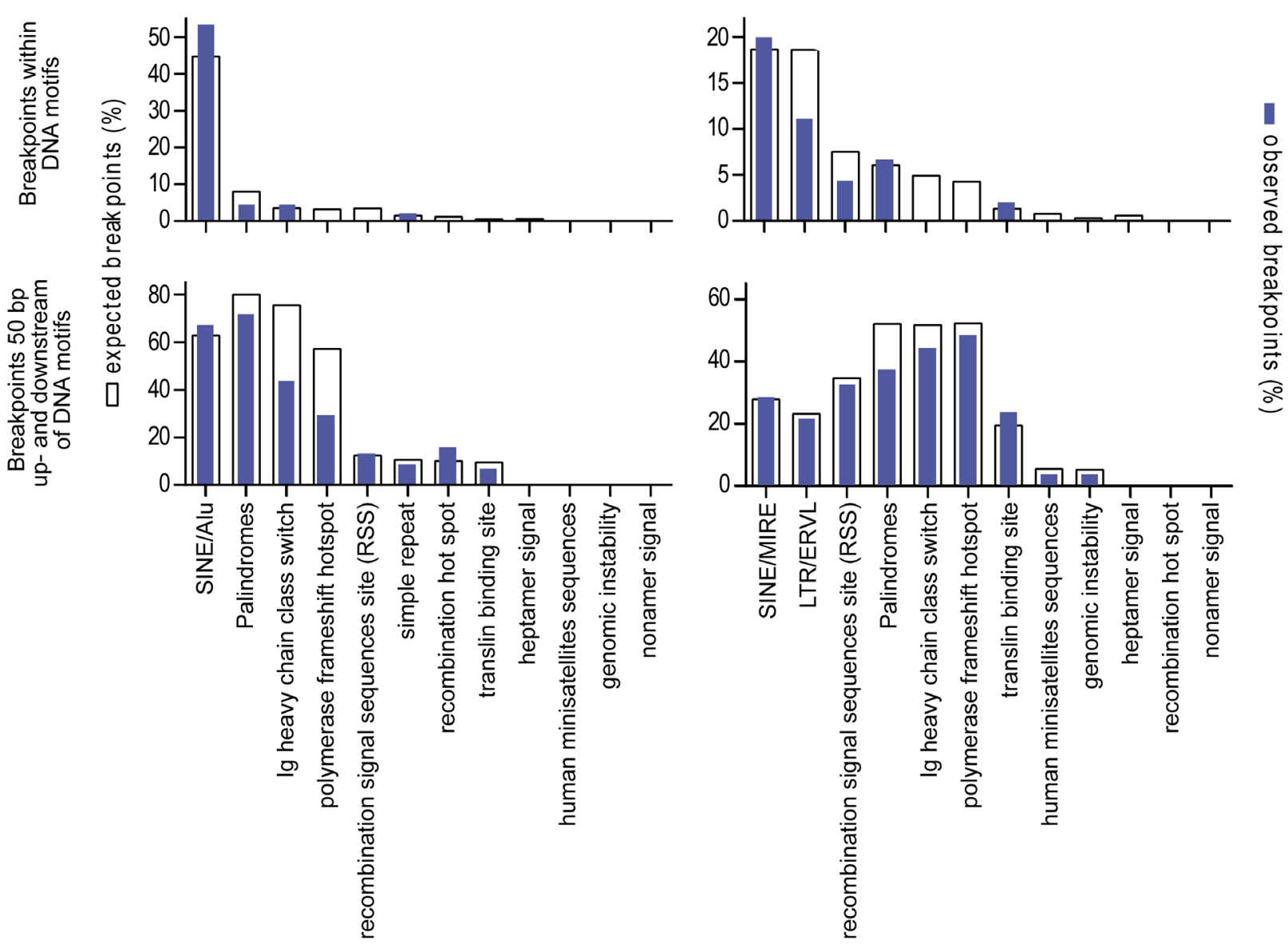

Figure 2: Localization of genomic breakpoints. Co-localization of genomic breakpoints to repeat regions and DNA sequence motifs that could support the initiation of ALCL chromosomal translocation. White columns represent the numbers of expected breakpoints; blue columns represent the numbers of observed breakpoints within the corresponding DNA motif.

A

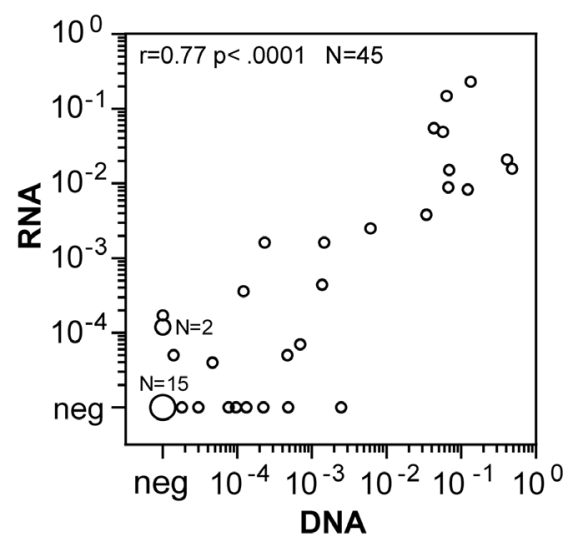

B

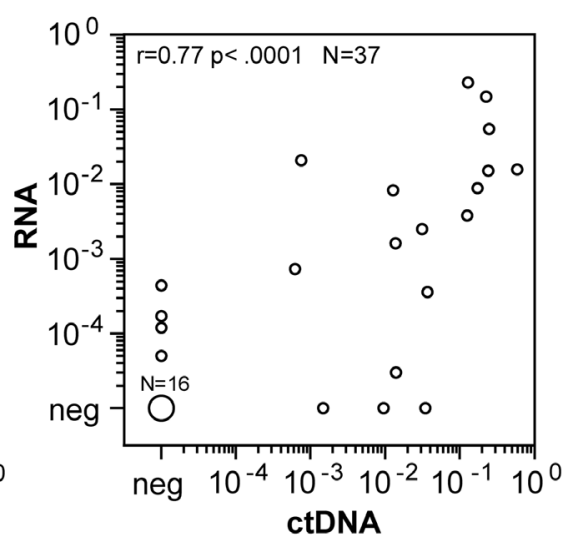

C

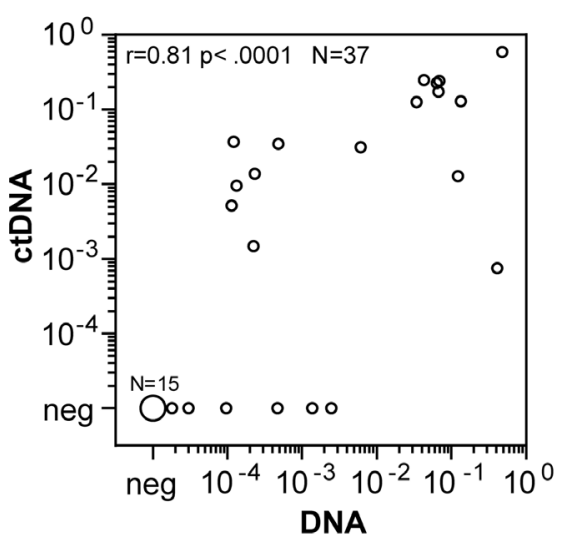

Figure 3: Comparison of quantitative NPM-ALK PCR results between cellular RNA, cellular DNA and cell free DNA. Comparison of $N P M-A L K$ copy numbers in blood or bone marrow samples from high risk ALCL-patients using the cellular RNA- and DNA-based and cell-free DNA-based methods. (A) Cell-based fusion transcripts (RNA) versus cellular fusion-sequence DNA-based (DNA), n=45. (B) Cell-based fusion transcripts (RNA) versus cell-free fusion-sequence DNA-based (ctDNA), n=37. (C) Cellular fusionsequence DNA-based (DNA) versus cell-free fusion-sequence DNA-based (ctDNA), $\mathrm{n}=37$. 
preparation for next generation sequencing may not offer substantial benefit for diagnostic laboratories.

The detailed sequence analysis of fusion site sequences revealed an NHEJ repair pattern similar to other chromosomal translocations in leukemia and sarcoma [26-31]. Features of VDJ recombination or AID signatures identified in B-cell lymphomas, Burkitt lymphoma, mantle cell lymphoma, or myeloma are not predominant in NPMALK-positive ALCL [21].

Detection and quantification of $N P M-A L K$ fusion transcripts (MDD) as well as early MRD measurement have been established as independent prognostic markers in children and adolescents with ALK-positive ALCL [15-
18]. We optimized the quantification of $N P M-A L K$ fusion genes by choosing patient-specific primer and probe sets from the individual fusion sequences. Our results applying both RNA- and DNA-based minimal disease assessments on patient samples show that the patient-specific NPM$A L K$ DNA breakpoints can be used to design primers allowing for minimal disease assessment with at least the same sensitivity as the standard RNA-based method. Quantified copy numbers of the NPM-ALK fusion gene and NPM-ALK fusion transcript correlate well. The results obtained by the RNA-based method have proven prognostic value for patients with ALCL. In addition, the method does not require identification of the DNA-

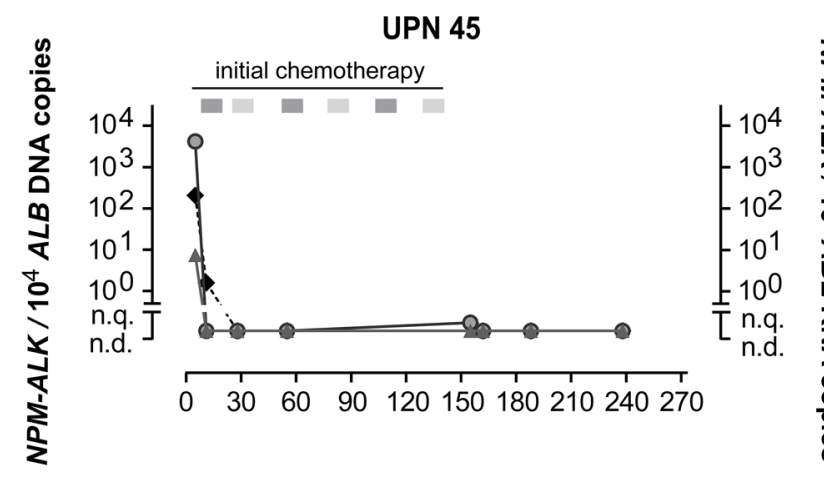

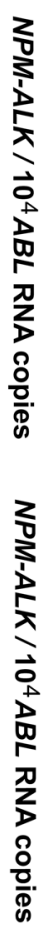

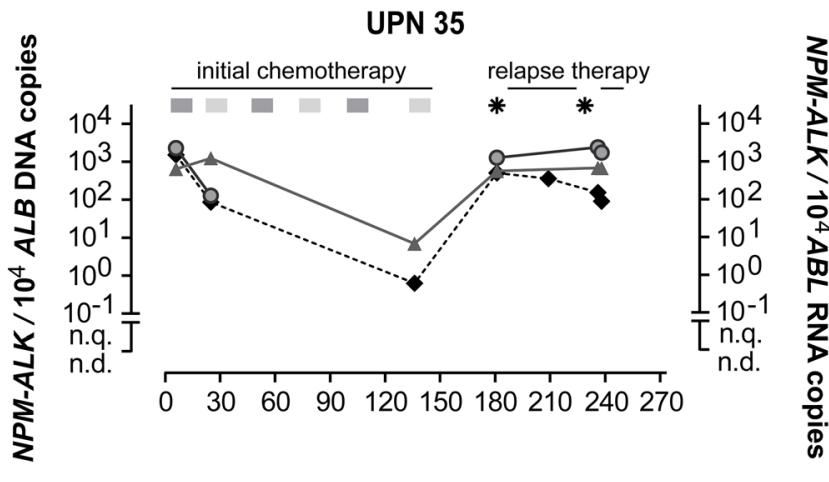

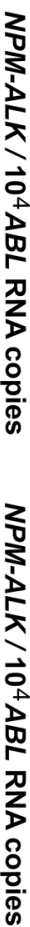

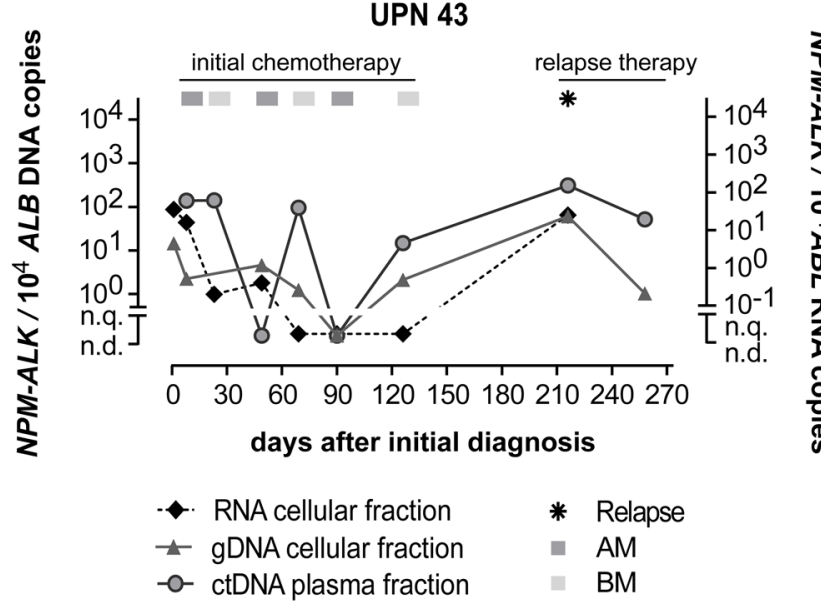

Figure 4: Quantification of NPM-ALK in ALCL patients. $N P M-A L K$ fusion RNA, DNA and ctDNA copies in 3 ALCL patients during their disease course. (AM... course of dexamethasone, methotrexate, ifosfamide, cytarabine and etoposide; BM... course of dexamethasone, methotrexate, cyclophosphamide and doxorubicine). 
breakpoint and development of a patient-specific assay. Therefore the assessment of MDD and MRD on the RNAlevel is the standard method during current chemotherapy. In addition, several examples show that MRD-analysis for $N P M-A L K$ transcripts is helpful for guiding treatment decisions in patients with very high risk or relapsed ALCL $[32,33]$. New treatment options against ALCL like ALKkinase inhibitors are arising. These agents induce cell cycle arrest in in vitro cell line experiments with variable effects on cell death [34, 35]. Clinically, rapid development of relapses with MRD-reappearance has been observed after discontinuation of crizotinib in patients treated with the drug for ALCL-relapse, suggesting that quiescent tumor cells that are detectable by DNA based methods, but are underestimated by RNA-based methods might exist [33]. We therefore suggest studying possible clinical implications of DNA-based MRD-screening in addition to the standard method in clinical trials with ALK-inhibitors. $\underline{\text { SR-786 }}$
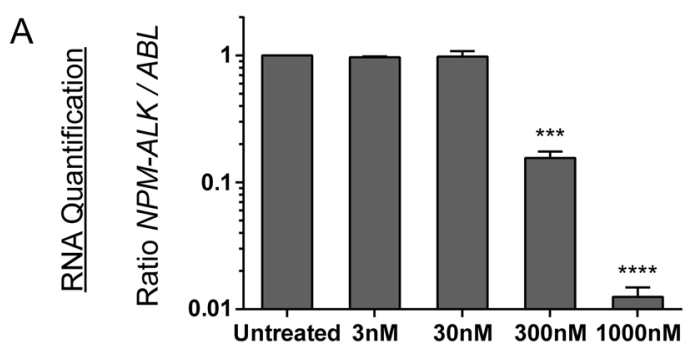

B

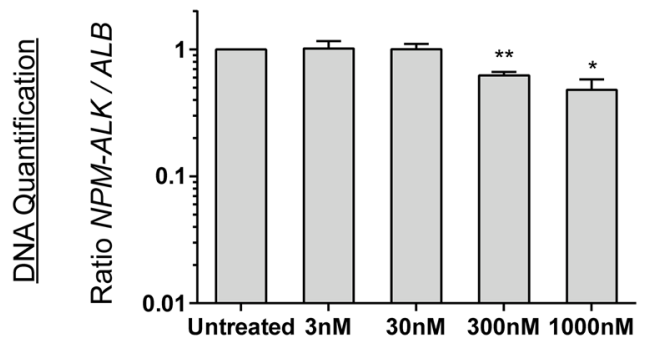

C

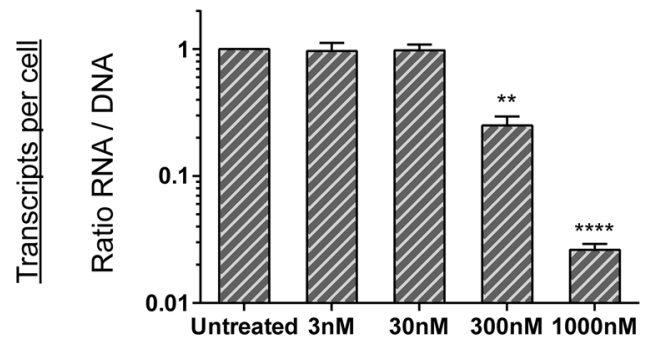

D

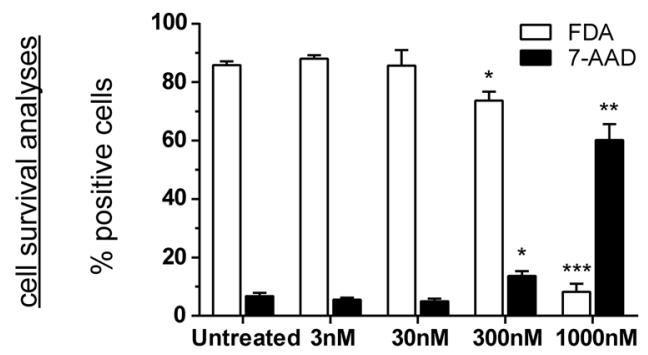

Karpas 299
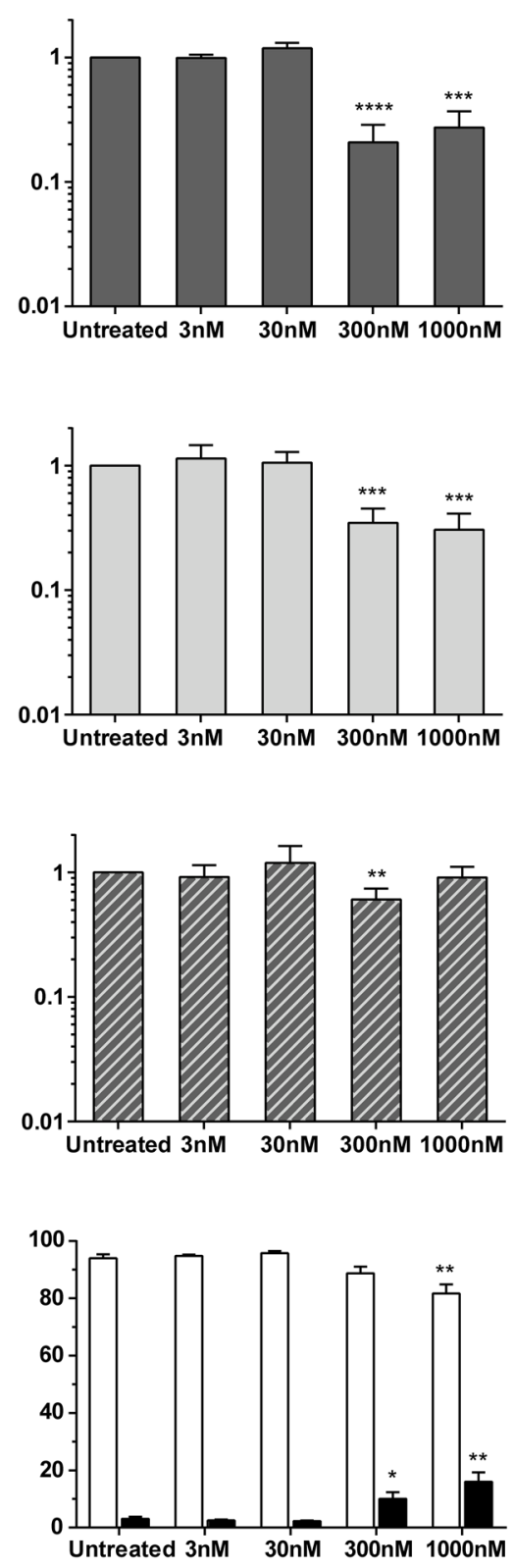

Figure 5: NPM-ALK quantification after crizotinib treatment in vitro. Parallel quantification of $N P M-A L K$ fusion transcript (A) and fusion gene (B) copies and cell survival analyses (D) after treatment of ALK-positive ALCL cell lines (SR-786 or Karpas 299) mixed 1:100 with an ALK-negative lymphoma cell line (DG75) with crizotinib for $72 \mathrm{~h}$. Transcripts per cell were calculated based on quantified RNA and DNA copies (C). Experiments were repeated three or five times for SR-786 and Karpas 299, respectively. ${ }^{* * * *} \mathrm{p}<0.0001,{ }^{* * *} \mathrm{p}$ $\left.<0.001,{ }^{* *} \mathrm{p}<0.01,{ }^{*} \mathrm{p}<0.05\right)$. 
The high stability of DNA furthermore enables the quantification of cell-free tumor DNA (ctDNA) that is released into the plasma from primary tumor and metastasis [36-38]. For many solid cancers, e.g., colorectal, lung, and breast cancer, or Ewing sarcoma, quantification of ctDNA has been established as a valuable tool for non-invasive therapy monitoring and even risk stratification [38-41].

Mussolin et al. investigated the presence of total cell-free DNA and NPM-ALK fusion sequences in initial plasma samples of 43 NPM-ALK-positive ALCL patients [42]. They used a SYBR green-based real-time PCR assay and the same primer pair for $N P M-A L K$ quantification for all patients. They observed no correlation of the total cell-free DNA with the presence or absence of MDD as determined by qualitative PCR for $N P M-A L K$ transcripts in mononuclear cells. In addition, their method did not analyze whether there was any association between the amount of cell-free NPM-ALK DNA and the presence or absence of MDD. In our patient-specific assays, genomic NPM-ALK copies in the patient's plasma correlated with both the amount of $N P M-A L K$ DNA and RNA fusion sequences in the cellular blood fraction, suggesting the release of tumor DNA from circulating cells or a sign of total tumor burden. The correlation of ctDNA with classical MDD/MRD quantification as well as the concordance of all results in samples obtained during therapy suggests a possible prognostic role for quantification ctDNA in patients with ALK-positive ALCL. However, that possibility will need to be further analyzed in a larger, unselected patient cohort.

In summary, we established a multiplex PCR assay for reliable identification of ALCL patients' individual genomic NPM-ALK fusion sequences that can be easily adopted for routine diagnostics and enables a DNAbased minimal disease monitoring for ALK-positive ALCL patients. We propose that supplementary MRD assessment including RNA and DNA quantification may allow for better understanding the mode of action of new targeted therapies and may contribute to improved therapy assessment and risk stratification by detecting quiescent tumor cells.

\section{MATERIALS AND METHODS}

\section{Patients and material}

Cryopreserved tumor material and EDTA-blood or -bone marrow from NPM-ALK-positive ALCL patients included in the Berlin-Frankfurt-Muenster group study NHL-BFM95 or the NHL-BFM Registry 2012, or German patients enrolled in the European intergroup trial ALCL99 was included in the analysis after informed consent of the patients or their legal guardians. Both the studies and the registry were approved by the institutional ethics committee of the primary investigator of the
NHL-BFM study group (A.R., W.W.). Tumor samples were available from 45 patients. The tumor material was from the initial biopsy in 25 patients and from a relapse biopsy in 15 patients, and the bone marrow or peripheral blood from five patients with high amount of circulating tumor cells measured by $N P M-A L K$-specific quantitative real-time PCR. Patient characteristics are shown in Table 1. The patient cohort was not representative with overrepresentation of relapse patients since tumor cells for sequencing was from relapse in several patients and infiltrated blood/bone marrow was used as well.

\section{Nested multiplex PCR assay for identification of genomic NPM-ALK fusion sites in ALCL patients}

The genomic NPM-ALK fusion sequence was analyzed in four ALCL cell lines (Karpas 299, SR-786, L-82, and SuDHL-1) and 45 ALCL patients. Genomic DNA was isolated from tumor samples, bone marrow, or blood samples by Trizol reagent (Thermo Fisher Scientific).

To amplify genomic $N P M-A L K$ fusion sequences, we developed a two-round multiplex PCR assay. For the first round, $100 \mathrm{ng}$ of DNA was combined with one forward primer located at the $5^{\prime}$ end of the NPM breakpoint cluster region $(\sim 1 \mathrm{~kb}$; exons $4-5$ [Chr5:170,818,710-170,819,820]) and five reverse primers covering the $A L K$ breakpoint cluster region $(\sim 2.2 \mathrm{~kb}$; exons 19-20 [Chr2:29,448,431-29,446,208]) to enable targeted amplification of PCR products with a maximal length of several hundred base pairs. Primer sequences are shown in Supplementary Table 2. Next, the amplified DNA was used in second-round single PCRs with corresponding nested primers. In five separate PCR reactions, the internal $N P M$ forward primer was combined with one of the five internal $A L K$ reverse primers to identify the $A L K$ primer located closest to the fusion site. Systematic optimization of multiplex PCR parameters was carried out with DNA from $N P M-A L K$-positive cell lines L-82 and SR-786. To calculate the sensitivity of the multiplex PCR assay, we quantified a dilution series of $N P M-A L K$-positive cells with $N P M-A L K$ negative HL60 cells were quantified. A minimum of one tumor cell in thousand wild-type cells can be detected by the multiplex PCR assay.

For identification of $A L K$ fusion sequences with less common fusion partner genes ATIC and TPM3 analogous nested multiplex PCR assays were established with one forward primer covering the breakpoint cluster region of ATIC ( $\sim 5.8 \mathrm{~kb}$; exons 7-8 [Chr2:216,191,545$216,197,230])$ and two forward primers covering the breakpoint cluster region of TPM3 ( 13 kb; exons 6-8 [Chr1:154,143,187-154,130,198]).

The amplification product was sequenced after purification with the QIAquick PCR Purification Kit (Qiagen). Patient-specific breakpoints were confirmed in 
an independent PCR using primer sets next to the patient's fusion site and $50 \mathrm{ng}$ original tumor DNA. All PCR reactions were performed with the LongAmp ${ }^{\circledR}$ Taq DNA Polymerase System (NEB) according to the manufacturer's instructions.

\section{Analysis of breakpoint characteristics}

Patient-specific $N P M-A L K$ fusion sequences were aligned to the human genome (hg19, UCSC Genome Browser). Breakpoint positions are listed in Table 1. Repeat elements at the fusion sites were identified with the RepeatMasker tool (http://www.repeatmasker. org/). Genomic fusion sites were then analyzed for colocalization with repeat elements, recombination-related DNA sequence motifs, Topoisomerase II binding sites, Translin binding sites, heptamer/nonamer recombination signals, recombination signal sequences (Recombination Signal Sequences Site tool, http://www.itb.cnr.it/rss/), palindromic sequences (EMBOSS explorer http:// emboss.bioinformatics.nl/cgi-bin/emboss/palindrome and Palindromic sequences finder tool http://www.biophp .org/minitools/find_palindromes/demo.php), human minisatellites core sequence, human minisatellites conserved sequence, hypervariable minisatellites recombination sequence, DNA polymerase frameshift hotspots, immunoglobulin heavy chain class switch repeats, LTR-IS motifs, and human replication origin consensus sequence.

Components of the free software environment $\mathrm{R}$ (http://www.r-project.org) were used for kernel density analysis as described previously [30].

\section{Quantification of tumor specific RNA, genomic DNA, and cell-free circulating DNA using the individual NPM-ALK fusion sequence}

As a proof of principle, eight high-risk patients with detectable $N P M-A L K$ fusion transcripts were monitored during treatment course by parallel quantification of the $N P M-A L K$ fusion transcript in blood or bone marrow cells, the NPM-ALK fusion gene in blood or bone marrow cells and the NPM-ALK fusion gene in cell-free plasma samples. In total, 50 RNA samples, 48 DNA samples and 42 plasma samples were analyzed. Genomic DNA and RNA were isolated from bone marrow or peripheral blood samples using Trizol reagent (Thermo Fisher Scientific). cDNA synthesis was performed using $1 \mu \mathrm{g}$ total RNA, random hexamers, and superscript II reverse transcriptase (Invitrogen). Cell-free circulating DNA was isolated from frozen plasma samples with the QIAamp Circulating Nucleic Acid Kit (Qiagen).

For MRD monitoring, the $N P M-A L K$ fusion transcripts (RNA) were quantified using real-time quantitative PCR as previously described [17]. Genomic $N P M-A L K$ fusion sequences (DNA) were quantified with digital droplet PCR QX200 Reader (BioRad) using patient individual breakpoint spanning primers and probe sets (Supplementary Table 3). To calculate the absolute number of NPM-ALK copies, the fusion-specific probe signal was normalized to a signal of the single-copy human albumin gene.

\section{Comparative analysis of $N P M-A L K$ fusion transcript and fusion gene levels after treatment of ALK+ ALCL cell lines with ALK kinase inhibitor}

NPM-ALK-positive (ALK+) cell lines Karpas 299 (a cell line with lower sensitivity to the ALK kinase inhibitor crizotinib) and SR-786 (a cell line with higher sensitivity to the ALK kinase inhibitor crizotinib) and NPM-ALK negative (ALK-) cell line DG-75 were obtained from the German Resource Centre for Biologic Material (DSMZ) and were cultured in RPMI medium supplemented with $10 \%$ fetal bovine serum, L-glutamine, and antibiotics at $37^{\circ} \mathrm{C}$ in $5 \% \mathrm{CO}_{2}$. The ALK kinase inhibitor crizotinib was obtained from Cell Signaling Technology. Stock solutions $(10 \mathrm{mM})$ were prepared with DMSO and stored at $-80^{\circ} \mathrm{C}$; working solutions were prepared with DMSO immediately before use.

50,000 ALK + cells were incubated with increasing concentrations (3 nM, $30 \mathrm{nM}, 300 \mathrm{nM}$ and $1000 \mathrm{nM}$, respectively) of crizotinib for $72 \mathrm{~h}$. To measure changes of NPM-ALK fusion genes and fusion gene transcripts under MRD conditions, 4,950,000 ALK- DG-75 cells were added for a dilution of 1:100.

For quantification of $N P M-A L K$ fusion transcripts and fusion genes, RNA and DNA were isolated in parallel using the AllPrep DNA/RNA Mini Kit (Qiagen). cDNA synthesis was performed with $1 \mu \mathrm{g}$ of RNA, random hexamer primers, and Superscript II reverse transcriptase (Invitrogen). NPM-ALK transcripts and fusion genes were quantified using fusion-sequence-spanning primers and probes (Supplementary Table 3). The NPM-ALK fusion transcript was normalized to the housekeeping gene $A B L 1$ to exclude experimental variation during the cDNA synthesis process. To calculate the absolute number of ALK + cells, the NPM-ALK fusion gene signal was normalized to a signal of the single copy gene albumin, which is equally detectable in ALK+ and ALK- cells.

In addition, 100,000 ALK+ (Karpas 299 and SR786) and ALK- cells (DG-75) were analyzed in two parallel experiments to assess the number of living and dead cells after $72 \mathrm{~h}$ of crizotinib treatment. To detect viable cells, the cell lines were incubated with $5 \mathrm{ng} /$ $\mathrm{ml}$ fluorescein diacetate (FDA) (Sigma) for 20 minutes at $37^{\circ} \mathrm{C}$. Cells were collected by centrifugation and re-dissolved in $200 \mu \mathrm{l}$ PBS. To detect dead cells, $10 \mu \mathrm{l}$ 7 -AAD solution (BD-biosciences) was added and the cells were stained on ice for 20 minutes [43]. The number of viable and dead cells was measured on a FACS Calibur 
flow cytometer with Cell Quest Pro software (BD biosciences). Analysis was performed with FlowJo 10 software (Miltenyi Biotech).

\section{Statistical analysis}

Co-localization of genomic breakpoints to repeat regions and DNA sequence motifs was statistically analyzed using the Fisher's exact test. Differences between mean values of the in vitro measurements were assessed with a one-way ANOVA test. MDD data from the quantification of the NPM-ALK fusion at the RNA, DNA, and ctDNA levels were compared using Spearman correlation statistics.

\section{Abbreviations}

ALCL: anaplastic large-cell lymphoma; MDD: minimal disseminated disease; MRD: minimal residual disease; NPM-ALK: Nucleophosmin-anaplastic lymphoma kinase.

\section{Author contributions}

MK, CDW, MM, and WW conceptualized and designed this study. MK, CDW, DS, and VS performed experiments. MK, CDW, JZ, DS, PC, MM, and WW collected and analyzed data. MZ contributed statistical analysis. MK, CDW, MM, and WW wrote the manuscript. All authors were involved in reviewing the final version.

\section{ACKNOWLEDGMENTS}

The authors thank Ursula Jacobs, Sabine Semper, and Jutta Schieferstein for excellent technical assistance.

\section{CONFLICTS OF INTEREST}

The authors declare no conflicts of interest.

\section{FUNDING}

This work was supported by a grant from Schornsteinfeger helfen krebskranken Kindern, Germany (grant to $\mathrm{MK}$ and $\mathrm{MM}$ ). CDW and $\mathrm{WW}$ received additional support from Forschungshilfe Peiper. The NHL-BFM-Registry 2012 is supported by a grant from the Deutsche Kinderkrebsstiftung (DKS 2014.11 A/B). PC is supported by the Interdisciplinary Centre for Clinical Research, FAU Erlangen-Nürnberg, Erlangen, Germany.

\section{REFERENCES}

1. Burkhardt B, Zimmermann M, Oschlies I, Niggli F, Mann G, Parwaresch R, Riehm H, Schrappe M, Reiter A; BFM Group. The impact of age and gender on biology, clinical features and treatment outcome of non-Hodgkin lymphoma in childhood and adolescence. Br J Haematol. 2005; 131:3949. https://doi.org/10.1111/j.1365-2141.2005.05735.x.

2. Morris SW, Kirstein MN, Valentine MB, Dittmer KG, Shapiro DN, Saltman DL, Look AT. Fusion of a kinase gene, ALK, to a nucleolar protein gene, NPM, in nonHodgkin's lymphoma. Science. 1994; 263:1281-4.

3. Damm-Welk C, Klapper W, Oschlies I, Gesk S, Rottgers S, Bradtke J, Siebert R, Reiter A, Woessmann W. Distribution of NPM1-ALK and X-ALK fusion transcripts in paediatric anaplastic large cell lymphoma: a molecular-histological correlation. Br J Haematol. 2009; 146:306-9. https://doi. org/10.1111/j.1365-2141.2009.07754.x.

4. Perkins SL, Pickering D, Lowe EJ, Zwick D, Abromowitch M, Davenport G, Cairo MS, Sanger WG. Childhood anaplastic large cell lymphoma has a high incidence of ALK gene rearrangement as determined by immunohistochemical staining and fluorescent in situ hybridisation: a genetic and pathological correlation. Br J Haematol. 2005; 131:624-7. https://doi.org/10.1111/j.1365-2141.2005.05808.x.

5. Chiarle R, Voena C, Ambrogio C, Piva R, Inghirami G. The anaplastic lymphoma kinase in the pathogenesis of cancer. Nat Rev Cancer. 2008; 8:11-23. https://doi.org/10.1038/ nrc2291.

6. Luthra R, Pugh WC, Waasdorp M, Morris W, Cabanillas F, Chan PK, Sarris AH. Mapping of genomic $t(2 ; 5)(\mathrm{p} 23 ; \mathrm{q} 35)$ break points in patients with anaplastic large cell lymphoma by sequencing long-range PCR products. Hematopathol Mol Hematol. 1998; 11:173-83.

7. Ladanyi M, Cavalchire G. Molecular variant of the NPMALK rearrangement of Ki-1 lymphoma involving a cryptic ALK splice site. Genes Chromosomes Cancer. 1996; 15:173-7.

8. Seidemann K, Tiemann M, Schrappe M, Yakisan E, Simonitsch I, Janka-Schaub G, Dorffel W, Zimmermann M, Mann G, Gadner H, Parwaresch R, Riehm H, Reiter A. Short-pulse B-non-Hodgkin lymphoma-type chemotherapy is efficacious treatment for pediatric anaplastic large cell lymphoma: a report of the Berlin-Frankfurt-Munster Group Trial NHL-BFM 90. Blood. 2001; 97:3699-706.

9. Brugieres L, Le Deley MC, Rosolen A, Williams D, Horibe K, Wrobel G, Mann G, Zsiros J, Uyttebroeck A, Marky I, Lamant L, Reiter A. Impact of the methotrexate administration dose on the need for intrathecal treatment in children and adolescents with anaplastic large-cell lymphoma: results of a randomized trial of the EICNHL Group. J Clin Oncol. 2009; 27:897-903. https://doi. org/10.1200/JCO.2008.18.1487.

10. Lowe EJ, Sposto R, Perkins SL, Gross TG, Finlay J, Zwick D, Abromowitch M; Children's Cancer Group Study 5941. Intensive chemotherapy for systemic anaplastic large cell lymphoma in children and adolescents: final results of Children's Cancer Group Study 5941. Pediatr Blood Cancer. 2009; 52:335-9. https://doi.org/10.1002/pbc.21817. 
11. Alexander S, Kraveka JM, Weitzman S, Lowe E, Smith L, Lynch JC, Chang M, Kinney MC, Perkins SL, Laver J, Gross TG, Weinstein H. Advanced stage anaplastic large cell lymphoma in children and adolescents: results of ANHL0131, a randomized phase III trial of APO versus a modified regimen with vinblastine: a report from the children's oncology group. Pediatr Blood Cancer. 2014; 61:2236-42. https://doi.org/10.1002/pbc.25187.

12. Pro B, Advani R, Brice P, Bartlett NL, Rosenblatt JD, Illidge T, Matous J, Ramchandren R, Fanale M, Connors JM, Yang Y, Sievers EL, Kennedy DA, et al. Brentuximab vedotin (SGN-35) in patients with relapsed or refractory systemic anaplastic large-cell lymphoma: results of a phase II study. J Clin Oncol. 2012; 30:2190-6. https://doi. org/10.1200/JCO.2011.38.0402.

13. Brugieres L, Pacquement H, Le Deley MC, Leverger G, Lutz P, Paillard C, Baruchel A, Frappaz D, Nelken B, Lamant L, Patte C. Single-drug vinblastine as salvage treatment for refractory or relapsed anaplastic large-cell lymphoma: a report from the French Society of Pediatric Oncology. J Clin Oncol. 2009; 27:5056-61. https://doi. org/10.1200/JCO.2008.20.1764.

14. Mosse YP, Voss SD, Lim MS, Rolland D, Minard CG, Fox E, Adamson P, Wilner K, Blaney SM, Weigel BJ. Targeting ALK With Crizotinib in Pediatric Anaplastic Large Cell Lymphoma and Inflammatory Myofibroblastic Tumor: A Children's Oncology Group Study. J Clin Oncol. 2017; 35:3215-21. https://doi.org/10.1200/JCO.2017.73.4830.

15. Mussolin L, Damm-Welk C, Pillon M, Zimmermann M, Franceschetto G, Pulford K, Reiter A, Rosolen A, Woessmann W. Use of minimal disseminated disease and immunity to NPM-ALK antigen to stratify ALK-positive ALCL patients with different prognosis. Leukemia. 2013; 27:416-22. https://doi.org/10.1038/leu.2012.205.

16. Mussolin L, Pillon M, d'Amore ES, Santoro N, Lombardi A, Fagioli F, Zanesco L, Rosolen A. Prevalence and clinical implications of bone marrow involvement in pediatric anaplastic large cell lymphoma. Leukemia. 2005; 19:16437. https://doi.org/10.1038/sj.leu.2403888.

17. Damm-Welk C, Busch K, Burkhardt B, Schieferstein J, Viehmann S, Oschlies I, Klapper W, Zimmermann M, Harbott J, Reiter A, Woessmann W. Prognostic significance of circulating tumor cells in bone marrow or peripheral blood as detected by qualitative and quantitative PCR in pediatric NPM-ALK-positive anaplastic largecell lymphoma. Blood. 2007; 110:670-7. https://doi. org/10.1182/blood-2007-02-066852.

18. Damm-Welk C, Mussolin L, Zimmermann M, Pillon M, Klapper W, Oschlies I, d'Amore ES, Reiter A, Woessmann W, Rosolen A. Early assessment of minimal residual disease identifies patients at very high relapse risk in NPM-ALKpositive anaplastic large-cell lymphoma. Blood. 2014; 123:334-7. https://doi.org/10.1182/blood-2013-09-526202.

19. Iijima-Yamashita Y, Mori T, Nakazawa A, Fukano R, Takimoto T, Tsurusawa M, Kobayashi R, Horibe K. Prognostic impact of minimal disseminated disease and immune response to NPM-ALK in Japanese children with ALK-positive anaplastic large cell lymphoma. Int J Hematol. 2018; 107:244250. https://doi.org/10.1007/s12185-017-2338-6.

20. Ghezraoui H, Piganeau M, Renouf B, Renaud JB, Sallmyr A, Ruis B, Oh S, Tomkinson AE, Hendrickson EA, Giovannangeli C, Jasin M, Brunet E. Chromosomal translocations in human cells are generated by canonical nonhomologous end-joining. Mol Cell. 2014; 55:829-42. https://doi.org/10.1016/j.molcel.2014.08.002.

21. Lieber MR. Mechanisms of human lymphoid chromosomal translocations. Nat Rev Cancer. 2016; 16:387-98. https:// doi.org/10.1038/nrc.2016.40.

22. Tsai AG, Lu H, Raghavan SC, Muschen M, Hsieh CL, Lieber MR. Human chromosomal translocations at $\mathrm{CpG}$ sites and a theoretical basis for their lineage and stage specificity. Cell. 2008; 135:1130-42. https://doi. org/10.1016/j.cell.2008.10.035.

23. Sarris AH, Luthra R, Cabanillas F, Morris SW, Pugh WC. Genomic DNA amplification and the detection of $\mathrm{t}(2 ; 5)$ (p23;q35) in lymphoid neoplasms. Leuk Lymphoma. 1998; 29:507-14. https://doi.org/10.3109/10428199809050910.

24. Beylot-Barry M, Groppi A, Vergier B, Pulford K, Merlio JP. Characterization of $\mathrm{t}(2 ; 5)$ reciprocal transcripts and genomic breakpoints in $\mathrm{CD} 30+$ cutaneous lymphoproliferations. Blood. 1998; 91:4668-76.

25. Yin CC, Luthra R. Detection of $t(2 ; 5)(\mathrm{p} 23 ; \mathrm{q} 35)$ in anaplastic large-cell lymphoma by long-range nested polymerase chain reaction assay. Methods Mol Biol. 2013; 999:217-22. https://doi.org/10.1007/978-1-62703-357-2_15.

26. Krumbholz M, Karl M, Tauer JT, Thiede C, Rascher W, Suttorp M, Metzler M. Genomic BCR-ABL1 breakpoints in pediatric chronic myeloid leukemia. Genes Chromosomes Cancer. 2012; 51:1045-53. https://doi.org/10.1002/ gcc. 21989.

27. Ross DM, O'Hely M, Bartley PA, Dang P, Score J, Goyne JM, Sobrinho-Simoes M, Cross NC, Melo JV, Speed TP, Hughes TP, Morley AA. Distribution of genomic breakpoints in chronic myeloid leukemia: analysis of 308 patients. Leukemia. 2013; 27:2105-7. https://doi. org/10.1038/leu.2013.116.

28. von Goessel H, Jacobs U, Semper S, Krumbholz M, Langer T, Keller T, Schrauder A, van der Velden VH, van Dongen JJ, Harbott J, Panzer-Grumayer ER, Schrappe M, Rascher W, et al. Cluster analysis of genomic ETV6-RUNX1 (TELAML1) fusion sites in childhood acute lymphoblastic leukemia. Leuk Res. 2009; 33:1082-8. https://doi. org/10.1016/j.leukres.2008.11.001.

29. Reiter A, Saussele S, Grimwade D, Wiemels JL, Segal MR, Lafage-Pochitaloff M, Walz C, Weisser A, Hochhaus A, Willer A, Reichert A, Buchner T, Lengfelder E, et al. Genomic anatomy of the specific reciprocal translocation $\mathrm{t}(15 ; 17)$ in acute promyelocytic leukemia. Genes Chromosomes Cancer. 2003; 36:175-88. https://doi. org/10.1002/gcc.10154. 
30. Berger M, Dirksen U, Braeuninger A, Koehler G, Juergens H, Krumbholz M, Metzler M. Genomic EWS-FLI1 fusion sequences in Ewing sarcoma resemble breakpoint characteristics of immature lymphoid malignancies. PLoS One. 2013; 8:e56408. https://doi.org/10.1371/journal. pone.0056408.

31. Mertens F, Antonescu CR, Mitelman F. Gene fusions in soft tissue tumors: Recurrent and overlapping pathogenetic themes. Genes Chromosomes Cancer. 2016; 55:291-310. https://doi.org/10.1002/gcc.22335.

32. Hebart H, Lang P, Woessmann W. Nivolumab for Refractory Anaplastic Large Cell Lymphoma: A Case Report. Ann Intern Med. 2016; 165:607-8. https://doi.org/10.7326/ L16-0037.

33. Gambacorti-Passerini C, Mussolin L, Brugieres L. Abrupt Relapse of ALK-Positive Lymphoma after Discontinuation of Crizotinib. N Engl J Med. 2016; 374:95-6. https://doi. org/10.1056/NEJMc1511045.

34. George SK, Vishwamitra D, Manshouri R, Shi P, Amin HM. The ALK inhibitor ASP3026 eradicates NPM-ALK(+) T-cell anaplastic large-cell lymphoma in vitro and in a systemic xenograft lymphoma model. Oncotarget. 2014; 5:5750-63. https://doi.org/10.18632/oncotarget.2170.

35. Turturro F, Frist AY, Arnold MD, Seth P, Pulford K. Biochemical differences between SUDHL-1 and KARPAS 299 cells derived from $\mathrm{t}(2 ; 5)$-positive anaplastic large cell lymphoma are responsible for the different sensitivity to the antiproliferative effect of p27(Kip1). Oncogene. 2001; 20:4466-75. https://doi.org/10.1038/sj.onc.1204582.

36. Crowley E, Di Nicolantonio F, Loupakis F, Bardelli A. Liquid biopsy: monitoring cancer-genetics in the blood. Nat Rev Clin Oncol. 2013; 10:472-84. https://doi.org/10.1038/ nrclinonc.2013.110.

37. Alix-Panabieres C, Schwarzenbach $H$, Pantel K. Circulating tumor cells and circulating tumor DNA. Annu
Rev Med. 2012; 63:199-215. https://doi.org/10.1146/ annurev-med-062310-094219.

38. Schwarzenbach H, Hoon DS, Pantel K. Cell-free nucleic acids as biomarkers in cancer patients. Nat Rev Cancer. 2011; 11:426-37. https://doi.org/10.1038/nrc3066.

39. Diehl F, Schmidt K, Choti MA, Romans K, Goodman S, Li M, Thornton K, Agrawal N, Sokoll L, Szabo SA, Kinzler KW, Vogelstein B, Diaz LA Jr. Circulating mutant DNA to assess tumor dynamics. Nat Med. 2008; 14:985-90. https:// doi.org/10.1038/nm.1789.

40. Dawson SJ, Tsui DW, Murtaza M, Biggs H, Rueda OM, Chin SF, Dunning MJ, Gale D, Forshew T, MahlerAraujo B, Rajan S, Humphray S, Becq J, et al. Analysis of circulating tumor DNA to monitor metastatic breast cancer. N Engl J Med. 2013; 368:1199-209. https://doi.org/10.1056/ NEJMoa1213261.

41. Krumbholz M, Hellberg J, Steif B, Bauerle T, Gillmann C, Fritscher T, Agaimy A, Frey B, Juengert J, Wardelmann E, Hartmann W, Juergens H, Dirksen U, et al. Genomic EWSR1 Fusion Sequence as Highly Sensitive and Dynamic Plasma Tumor Marker in Ewing Sarcoma. Clin Cancer Res. 2016; 22:4356-65. https://doi.org/10.1158/1078-0432. CCR-15-3028.

42. Mussolin L, Burnelli R, Pillon M, Carraro E, Farruggia P, Todesco A, Mascarin M, Rosolen A. Plasma cell-free DNA in paediatric lymphomas. J Cancer. 2013; 4:323-9. https:// doi.org/10.7150/jca.6226.

43. Jones KH, Senft JA. An improved method to determine cell viability by simultaneous staining with fluorescein diacetate-propidium iodide. J Histochem Cytochem. 1985; 33:77-9. https://doi.org/10.1177/33.1.2578146. 